\title{
Thermobifida cellulolytica sp. nov., a novel lignocellulose-decomposing actinomycete
}

\footnotetext{
${ }^{1}$ Department of Microbiology, Szent István University, Páter K. u. 1., Gödöllö, H-2103, Hungary

2 Centre of Microbial and Plant Genetics, Katholieke Universiteit Leuven, Kasteelpark Arenberg 20, B-3001, Belgium

${ }^{3}$ Plant Protection Institute, Hungarian Academy of Sciences, 1525 Budapest PO Box 102, Hungary

${ }^{4}$ Department of Microbiology, Eötvös Loránd University, Múzeum krt. 4/a, Budapest, H-1088, Hungary

${ }^{5}$ Agricultural Biotechnology Centre, Gödöllő, H-2101, PO Box 411, Hungary
}

\author{
József Kukolya, ${ }^{1}$ István Nagy, ${ }^{2}$ Miklós Láday, ${ }^{3}$ Erika Tóth, ${ }^{4}$ \\ Orsolya Oravecz, ${ }^{4}$ Károly Márialigeti ${ }^{4}$ and László Hornok ${ }^{1,5}$
}

\begin{abstract}
Author for correspondence: József Kukolya. Tel: +3628410 616. Fax: + 3628410804. e-mail:kukolya@abc.hu
\end{abstract}

\begin{abstract}
Four actinomycete strains, isolated from the overheated region of manure compost, were assigned to the genus Thermobifida on the basis of morphological, physiological and biochemical characteristics. All strains produced single, ovoid, heat-sensitive spores on dichotomically branched aerial hyphae. On the basis of chemotaxonomic traits, these isolates showed strong affinity towards members of the genus Thermobifida. Cell-wall analysis revealed the presence of meso-diaminopimelic acid, but no other characteristic amino acids or sugars in the murein (cell wall type III). According to polar lipid analysis, all strains showed PL II-type phospholipid composition; phosphatidylethanolamine and glycolipid were detected together with some unidentified phospholipids. The isoprenoid quinone composition of the new isolates differed slightly from that of the other two Thermobifida species described thus far. The partial 16S rDNA sequence similarity of the four strains reached $99 \cdot 8-100 \%$, whereas a nearly complete $16 \mathrm{~S}$ rDNA sequence of TB100', the representative strain of this collection, showed only 97.4 and $97.8 \%$ similarity to the corresponding rDNA sequences of the type strains of Thermobifida fusca and Thermobifida alba, respectively. These four isolates constituted a homogeneous group with levels of DNA-DNA homology ranging from 94.6 to $99 \cdot 1 \%$. The DNA-DNA relative homology values of strain TB100' to Thermobifida fusca ATCC $27730^{\top}$ and Thermobifida alba DSM $43795^{\top}$ were $48 \cdot 1$ and $57 \%$, respectively. On the basis of phenotypic, chemotaxonomic and genotypic data, the strains are assigned to a new species within the genus Thermobifida under the name Thermobifida cellulolytica sp. nov. The type

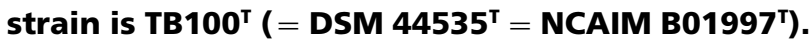

Keywords: Thermomonospora, Thermobifida, cellulolytic actinomycetes, Thermobifida cellulolytica sp. nov. cellulolytica sp. nov.

\section{INTRODUCTION}

The genus Thermobifida was constructed by Zhang et al. (1998) for actinomycetes assigned originally to the highly heterogeneous genus Thermomonospora. Six species of Thermomonospora, including Thermomonospora fusca and Thermomonospora alba, have formerly

Stereoscopic images of spore clusters of Thermobifida cellulolytica are available as supplementary data in IJSEM Online (http://ijs. sgmjournals.org).

The GenBank/EMBL/DDBJ accession numbers for partial 16S rRNA gene sequences are AJ298058, AJ298061, AJ29060 and AJ298059 for strains $\mathrm{TB}^{100}{ }^{\top}$, TB110, TB108 and K21, respectively. been accepted and listed in the 9th edition of Bergey's Manual of Determinative Bacteriology (Holt et al., 1994). Phylogenetic analysis, based on 16S rRNA sequences, resulted in a reclassification of this group of actinomycetes. Thermomonospora curvata was the only species left in the genus Thermomonospora, Thermomonospora mesophila was transferred into Microbispora, and Thermomonospora formosensis was moved to the genus Actinomadura, whereas Thermobifida fusca and Thermobifida alba were affiliated into a new genus, Thermobifida gen. nov., belonging to the family Nocardiopsaceae; Thermobifida alba was designated as the type species. The taxonomic position of Thermomonospora chromogena remained uncertain. 
Members of the genus Thermobifida are Gram-positive, non acid-fast, chemo-organotrophic aerobic organisms that form an extensively branched substrate mycelium. They produce single, heat-sensitive spores borne on dichotomously branched sporophores forming dense spore clusters. Their cell walls contain meso-diaminopimelic acid (wall chemotype III), they are rich in fatty acids of the iso and anteiso series (fatty acid type $3 \mathrm{e})$ and contain MK-10 $\left(\mathrm{H}_{6}\right), \mathrm{MK}-10\left(\mathrm{H}_{8}\right)$ and MK-11 $\left(\mathrm{H}_{6}\right)$ menaquinones (menaquinone type $4 \mathrm{D}$ ); the major polar lipids are phosphatidylethanolamine and glycolipid (the phospholipid pattern is type II). The habitats are soil, manures and overheated compost. The outstanding cellulose-decomposing capability is the major characteristic feature of strains assigned to this two-membered new genus.

Searches for lignocellulolytic actinomycetes from the hot core of manure compost yielded the isolation of four strains (K21, TB100 ${ }^{\mathrm{T}}$, TB108, TB110) with morphological structures typical of the genus Thermobifida. All strains showed high levels of cellulase (including cellobiohydrolase and endoglucanase), endoxylanase, mannosidase, protease and amylase activity, as well as lignin-solubilization activity (Kukolya et al., 1997).

In this paper, we report the morphological, physiological, chemotaxonomical and genetic characteristics of these isolates. The detailed description of a new species, Thermobifida cellulolytica sp. nov., is also presented.

\section{METHODS}

Strains and culture conditions. The strains used in this study were $\mathrm{K} 21, \mathrm{~TB} 100^{\mathrm{T}}$, TB108 and TB110, isolated as described earlier (Kukolya et al., 1997); Thermobifida fusca ATCC 27730 was the reference strain. They were preserved in lyophilized ampoules as mixtures of freeze-dried spores and vegetative mycelium. Working stock cultures were maintained on MN300 cellulose agar (Kukolya et al., 1997). The inocula used for physiological tests were grown in LuriaBertani medium or saccharose broth $(0.5 \mathrm{~g}$ yeast extract, $1 \mathrm{~g}$ $\mathrm{NaNO}_{3}, 1 \mathrm{~g} \mathrm{~K}_{2} \mathrm{HPO}_{4}, 0 \cdot 3 \mathrm{~g} \mathrm{KCl}, 0.05 \mathrm{~g} \mathrm{MgSO}_{4} .7 \mathrm{H}_{2} \mathrm{O}, 10 \mathrm{~g}$ saccharose, 11 distilled water, $\mathrm{pH}$ 7.4). The biomass used for extraction of DNA was produced in Luria-Bertaini broth as shaken culture (200 r.p.m. at $50^{\circ} \mathrm{C}$ ).

Morphological observations. Colony morphology was examined on cultures grown for 7 days at $40{ }^{\circ} \mathrm{C}$ (strain K21) or $50^{\circ} \mathrm{C}$ (strains $\mathrm{TB} 100^{\mathrm{T}}$, TB108, TB110) on MN300 agar. Micro-morphology and sporulation were determined by light microscopy and scanning electron microscopy. Mycelia scraped off the agar plates after 4 days incubation were fixed overnight in Plumel's cacodylate buffer ( $\mathrm{pH} 7 \cdot 0$, containing $2.5 \%$ glutaraldehyde), dehydrated through a graded acetone series, critical-point dried from liquid $\mathrm{CO}_{2}$, and sputter coated with gold. The samples were examined with a Zeiss EM910 electron microscope at $40 \mathrm{kV}$.

Physiological tests. Physiological tests, including production of acid from carbohydrates, $\mathrm{pH}$ sensitivity and spore heat resistance, were determined as described by McCarthy (1989). Growth temperature ranges were determined by culturing the strains on MN300 agar at 28, 30, 35, 40, 44, 50, $55,57,61,66$ and $69^{\circ} \mathrm{C}$ for 7 days. Antibiotic sensitivity was tested on saccharose broth at concentrations of $1 \cdot 25,2 \cdot 5,5 \cdot 0$, $10 \cdot 0$ and $20 \cdot 0 \mu \mathrm{g} \mathrm{ml}^{-1}$.

Carbon-source utilization. Utilization of carbon sources was tested by using the mineral salts medium of McCarthy (1989). Each carbon source, sterilized by membrane filtration, was added to the medium to give a final concentration of $1 \%(\mathrm{w} / \mathrm{v})$. After 7 days incubation at $40{ }^{\circ} \mathrm{C}$ (for strain K21) or $50^{\circ} \mathrm{C}$ (for the other strains), growth was compared with that measured on the negative and positive control plates (basal medium without a carbon source or supplemented with glucose, respectively).

Degradative tests. Polysaccharide-degradation activities were determined on mineral salts plates containing $1 \%$ (w/v) crystalline cellulose (MN300; Machery Nagel), $0 \cdot 2 \%$ colloidal chitin, $0 \cdot 2 \%$ medium viscosity CM-cellulose (Sigma), $0.2 \%$ birch-wood xylan (Sigma) or $1 \%$ maize starch (Sigma). After $48 \mathrm{~h}$ incubation at the optimum temperature, CM-cellulose and xylan hydrolyses were visualized by staining with Congo red (Sazci et al., 1986); starch degradation was visualized by staining the plates with $5 \times$ diluted Gram's iodine for $5 \mathrm{~min}$. Crystalline celluloseand chitin-decomposition activities were detected as clearing zones around the colonies after 7 days incubation. Ligninsolubilization activity was measured by the method of Trigo \& Ball (1994) by using $1 \%(\mathrm{w} / \mathrm{v})$ ball-milled straw as the carbon source. The formation of an acid-precipitable lignocarbohydrate complex was measured spectrophotometrically according to Trigo \& Ball (1994). Degradation of elastin, Tween 20, Tween 80, casein and arbutin was determined by using the procedure of McCarthy \& Cross (1984).

Chemotaxonomic characterization. The cell-wall diamino acid and the sugar patterns of the four strains were determined from whole-cell hydrolysates as described by Hasegawa \& Takizawa (1983). Isoprenoid quinones were extracted according to the method of Collins et al. (1977) and the profile was analysed by HPLC (HP 1100) (Groth et al., 1997). Cellular fatty acids were extracted according to Stead et al. (1992) and were analysed by GC (Groth et al., 1996). Polar lipids were determined according to the method described by Minnikin et al. (1979). Mycolic acids were tested as recommended by Minnikin et al. (1975).

DNA base composition. The $\mathrm{G}+\mathrm{C}$ content ( $\mathrm{mol} \%$ ) of the DNA was determined spectrophotometrically from the midpoint of thermal denaturation in $0 \cdot 1 \times$ standard saline citrate by the method of English et al. (1999), using Cellulomonas flavigena DSM 20109 as the reference strain.

DNA-DNA hybridization. The reaction mixture consisted of $75 \mu \mathrm{g}$ sheared (400-600 bp) DNA ml ${ }^{-1}$ in $3 \times \mathrm{SSC}(1 \times \mathrm{SSC}$ is $0.15 \mathrm{M} \mathrm{NaCl}, 0.015 \mathrm{M} \mathrm{Na}_{3}$-citrate at $\left.\mathrm{pH} 7.6\right)$ and $25 \%$ DMSO. DNA was denaturated for $10 \mathrm{~min}$ at $95^{\circ} \mathrm{C}$. Reassociations were run at $60^{\circ} \mathrm{C}\left(T_{\mathrm{m}} 23^{\circ} \mathrm{C}\right)$ for $300 \mathrm{~min}$. The standard error was $4 \%$. The absorbance of the DNA was recorded at $258 \mathrm{~nm}$. Absorbance signals were logged at 1 min intervals. The $\mathrm{C}_{0} \mathrm{t}_{0.5}$ values and the percentage DNA relatedness were calculated as described by Labeda (1992).

165 rDNA sequencing. DNA was extracted from cells according to the methods of Hunter (1985). PCR amplification of $16 \mathrm{~S}$ rDNA was performed as described by Rainey et al. (1996). PCR products were purified with the PrepA-Gene kit (Bio-Rad) according to the manufacturer's 
instructions. Sequencing reactions were performed using the BigDye terminator cycle sequencing kit with AmpliTaq DNA polymerase (Applied Biosystems) according to the manufacturer's instructions. Partial sequences of the first $500 \mathrm{bp}$ of the $16 \mathrm{~S}$ rDNA were initiated with the $531 \mathrm{r}$ conservative eubacterial primer. The almost complete sequence of the $16 \mathrm{~S}$ rDNA of strain $\mathrm{TB} 100^{\mathrm{T}}$ was determined by using the primers 357f, 531r, 803f and 1114f. Sequences obtained by an ABI PRISM 310 automated sequencer were aligned manually and analysed with the ARB phylogenetic package. Reference sequences were taken from the Ribosomal Database Project (Maidak et al., 1999). Phylogenetic trees were reconstructed by the neighbour-joining (Saitou \& Nei, 1987), the De Soete tree fit (De Soete, 1983), and the maximum-parsimony (Fitch, 1971) methods. Bootstrapping was used to determine the confidence level of the tree topology.

\section{RESULTS AND DISCUSSION}

\section{Cultural, physiological and biochemical characteristics}

All strains shared a number of phenotypic properties consistent with their assignment to the genus Thermobifida (Table 1). They formed highly branched substrate mycelium and heat-sensitive spores (1$1.3 \times 0.6 \mu \mathrm{m}$ ) on aerial hyphae, on the tips of branched sporophores (Fig. 1). Repeated sporophore branching resulted in the formation of dense spore clusters (Fig. 2 ), as revealed by scanning electron microscopy. The surfaces of the spores became scaly upon maturation, giving a pine-cone appearance for these structures. Growth temperature ranges were $28-50{ }^{\circ} \mathrm{C}$ for strain $\mathrm{K} 21,44-57{ }^{\circ} \mathrm{C}$ for strain $\mathrm{TB} 100^{\mathrm{T}}, 44-61{ }^{\circ} \mathrm{C}$ for strain

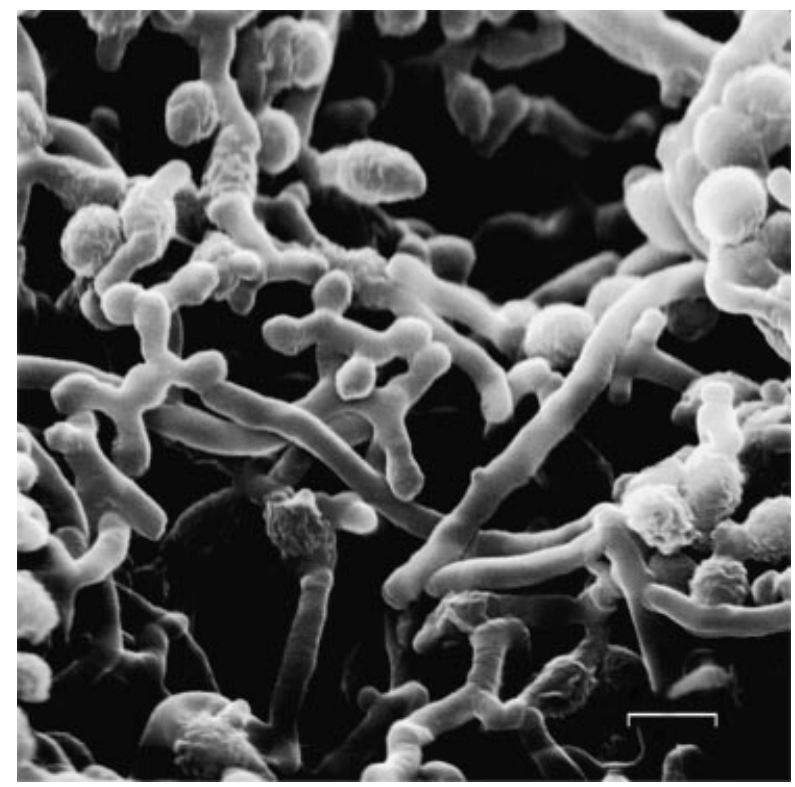

Fig. 1. Spores of strain $\mathrm{TB} 100^{\top}$ of Thermobifida cellulolytica sp. nov. formed on aerial hyphae, on the tips of branched sporophores. Bar, $1 \mu \mathrm{m}$.

TB108 and $44-66{ }^{\circ} \mathrm{C}$ for $\mathrm{TB} 110$ and the reference strain, Thermobifida fusca ATCC 27730. All strains tolerated a $\mathrm{pH}$ increase up to $10 \cdot 0$, a value approaching that actually measured in the sampling region of the compost pile where these actinomycetes were found. Of the carbon sources tested, all four strains were able

Table 1. Phenotypic characteristics of Thermobifida cellulolytica strains isolated from manure compost and of the reference strain Thermobifida fusca (ATCC 27730')

\begin{tabular}{|c|c|c|c|c|c|}
\hline Characteristic & K21 & $\mathrm{TB100}^{\mathrm{T}}$ & TB108 & TB110 & $\begin{array}{c}\text { T. fusca } \\
\text { ATCC } 27730^{\mathrm{T}}\end{array}$ \\
\hline Abundant white aerial mycelium & - & + & + & + & + \\
\hline Soluble pigments on MN300 agar & Pale brown & - & - & Yellowish-brown & - \\
\hline Spore size $(\mu \mathrm{m})$ & $1 \times 0 \cdot 5$ & $1 \cdot 1 \times 0 \cdot 6$ & $1.3 \times 0.6$ & $1 \cdot 1 \times 0 \cdot 6$ & $1 \times 0 \cdot 6$ \\
\hline Degradation of agar-agar & - & - & - & + & + \\
\hline \multicolumn{6}{|l|}{ Growth on sole carbon sources: } \\
\hline Adonitol & + & + & - & - & + \\
\hline L-Arabinose & - & - & + & - & - \\
\hline Glycerol* & - & - & - & - & + \\
\hline L-Rhamnose & - & + & + & - & - \\
\hline D-Melibiose & + & - & + & - & - \\
\hline Raffinose & - & + & + & + & + \\
\hline D-Ribose & - & + & + & + & - \\
\hline Acid produced from glucose* & - & - & - & - & + \\
\hline \multicolumn{6}{|l|}{ Growth with: } \\
\hline Erythromycin $\left(20 \mu \mathrm{g} \mathrm{ml}^{-1}\right)^{*}$ & + & + & + & + & - \\
\hline Tetracycline $\mathrm{HCl}\left(2 \cdot 5 \mu \mathrm{g} \mathrm{ml}^{-1}\right)$ & - & + & - & - & - \\
\hline
\end{tabular}

* Traits that are consequently different in the newly described strains and in the type strain of the genus Thermobifida (Thermobifida fusca ATCC 27730 ). 


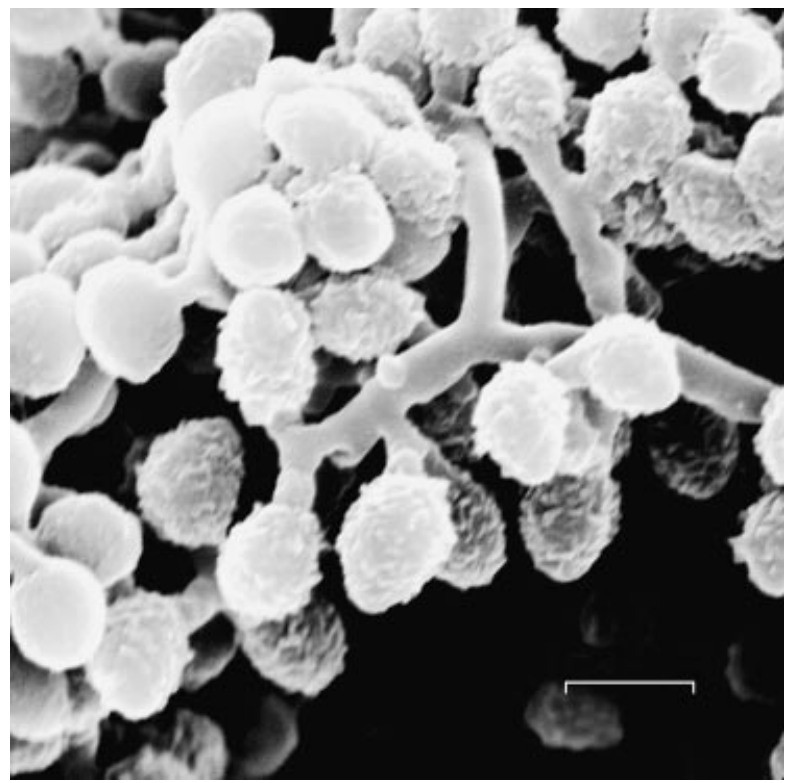

Fig. 2. Repeated sporophore branching resulting in the formation of dense spore clusters in strain TB110 of Thermobifida cellulolytica sp. nov. Bar, $1 \mu \mathrm{m}$. Stereoscopic images of spore clusters are available as supplementary data in IJSEM Online (http://ijs.sgmjournals.org).

to utilize D-xylose, D-mannose, D-glucose, D-galactose, $\mathrm{D}$-fructose, cellobiose, maltose, lactose, sucrose, trehalose and melezitose, but not L-sorbose, glycerol, meso-inositol, dulcitol or D-sorbitol. The strains degraded elastin, Tween 20, Tween 80 , arbutin, casein,
CM-cellulose, xylan and starch, and were able to solubilize lignocellulose substrate. All strains showed high cellulase activity on crystalline cellulose, and the clearing zones observed on MN300 agar plates indicated the presence of a complete cellulase enzyme system. Chitinase activity was absent. Thermobifida fusca and Thermobifida alba are also efficient cellulolytic organisms and lack chitinase activity (McCarthy, 1989). The strains were all susceptible to novobiocin $\left(10 \mu \mathrm{g} \mathrm{ml}^{-1}\right)$, ampicillin $\left(10 \mu \mathrm{g} \mathrm{ml}^{-1}\right)$, chloramphenicol $\left(10 \mu \mathrm{g} \mathrm{ml}^{-1}\right)$, kanamycin $\left(2 \cdot 5 \mu \mathrm{g} \mathrm{ml}^{-1}\right)$, streptomycin $\left(2.5 \mu \mathrm{g} \mathrm{ml}^{-1}\right)$, tetracycline hydrochloride $\left(5 \mu \mathrm{g} \mathrm{ml}^{-1}\right)$, apramycin $\left(2.5 \mu \mathrm{g} \mathrm{ml}^{-1}\right)$, thiostrepton $\left(1.25 \mu \mathrm{g} \mathrm{ml}^{-1}\right)$, penicillin $\left(10 \mu \mathrm{g} \mathrm{ml}^{-1}\right)$ and amoxycillin $\left(10 \mu \mathrm{g} \mathrm{ml}^{-1}\right)$. They were resistant to erythromycin at $20 \mu \mathrm{g} \mathrm{ml}^{-1}$.

\section{Chemotaxonomic properties}

The chemotaxonomic properties are summarized in Table 2. The cell wall contained meso-diaminopimelic acid as the murein diamino acid, and no characteristic sugar was detected, indicating the presence of wall chemotype III and sugar pattern type C. The major isoprenoid quinones were octa- and hexahydrogenated menaquinones with 10 isoprenoid units $\left[\mathrm{MK}-10\left(\mathrm{H}_{8}\right)\right.$, MK-10( $\left.\mathrm{H}_{6}\right)$ ]. According to Kroppenstedt (1985), these values indicate menaquinone pattern type $4 \mathrm{D}$, which is a diagnostic trait for the genus Thermobifida. Substantial amounts of uncommon menaquinones [MK$11\left(\mathrm{H}_{6}\right)$, MK- $\left.8\left(\mathrm{H}_{6}\right)\right]$ were also present in all strains, whereas the MK-10 $\left(\mathrm{H}_{4}\right)$ fraction was identified only in the three thermophilic strains. This menaquinone profile differs characteristically from that of the two known species of Thermobifida, Thermobifida alba and

Table 2. Chemotaxonomic traits of Thermobifida strains isolated from manure compost

Polar lipid analysis: all strains had phosphatidylethanolamine and glycolipid.

\begin{tabular}{|c|c|c|c|c|}
\hline Strain & K21 & $\mathrm{TB} 100^{\mathrm{T}}$ & TB108 & TB110 \\
\hline \multicolumn{5}{|c|}{ Cellular fatty acid analysis* } \\
\hline $15: 0$ iso & $4 \cdot 3$ & $18 \cdot 5$ & $16 \cdot 61$ & $2 \cdot 46$ \\
\hline $15: 0$ anteiso & $1 \cdot 8$ & 3.07 & $3 \cdot 35$ & $1 \cdot 08$ \\
\hline $16: 0$ iso & $23 \cdot 92$ & $14 \cdot 81$ & 13.98 & $20 \cdot 12$ \\
\hline $16: 0$ & $2 \cdot 3$ & $0 \cdot 5$ & $0 \cdot 2$ & $4 \cdot 35$ \\
\hline $17: 0$ iso & $32 \cdot 14$ & - & - & - \\
\hline $17: 0$ anteiso & - & $32 \cdot 2$ & $33 \cdot 74$ & $35 \cdot 84$ \\
\hline $17: 0$ cyclo $9-10$ & $21 \cdot 64$ & $19 \cdot 6$ & $24 \cdot 62$ & $15 \cdot 91$ \\
\hline $17: 0$ & $1 \cdot 1$ & $2 \cdot 5$ & $0 \cdot 26$ & $2 \cdot 35$ \\
\hline $18: 2 c i s 9,12$ & $7 \cdot 03$ & 4.95 & $1 \cdot 65$ & $7 \cdot 17$ \\
\hline $18: 0$ & 4.59 & - & - & $9 \cdot 78$ \\
\hline Total $(\%)$ & $98 \cdot 82$ & $96 \cdot 13$ & $94 \cdot 41$ & 99.06 \\
\hline $\begin{array}{l}\text { Analysis of isoprenoid } \\
\text { quinones } \dagger\end{array}$ & $\begin{array}{l}\text { MK-8 }\left(\mathrm{H}_{6}\right) \\
\left.\text { MK-11( } \mathrm{H}_{6}\right)\end{array}$ & $\begin{array}{l}\text { MK-10 }\left(\mathrm{H}_{4}\right), \text { MK-8 }\left(\mathrm{H}_{6}\right), \\
\text { MK-11( }\left(\mathrm{H}_{6}\right), \text { MK-8( }\left(\mathrm{H}_{4}\right)\end{array}$ & $\begin{array}{l}\left.\text { MK-10( }\left(\mathrm{H}_{4}\right), \text { MK-11( } \mathrm{H}_{6}\right), \\
\left.\text { MK-8( } \mathrm{H}_{6}\right)\end{array}$ & $\begin{array}{l}\left.\text { MK-11( } \mathrm{H}_{6}\right), \text { MK-8 }\left(\mathrm{H}_{6}\right), \\
\text { MK-10( }\left(\mathrm{H}_{4}\right)\end{array}$ \\
\hline
\end{tabular}

* Values less than $1 \%$ are not shown.

$\uparrow$ All strains had MK-10( $\left.\mathrm{H}_{8}\right)$ and MK-10( $\left.\mathrm{H}_{6}\right)$ as major components. 


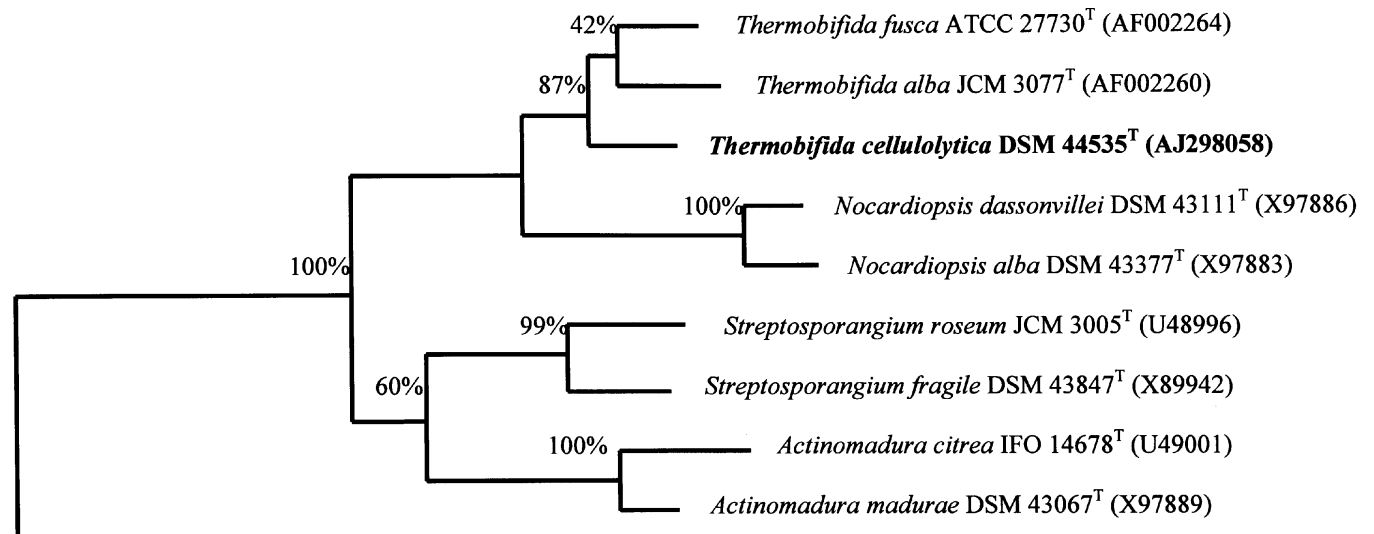

Thermobispora bispora ATCC $19993^{\mathrm{T}}$ (U58523)

0.10

Fig. 3. Neighbour-joining tree based on 16S rDNA sequences of Thermobifida cellulolytica sp. nov., other Thermobifida strains, and their close relatives. Bootstrap values are calculated from 1000 repeats. Bar, 10 nucleotide substitutions per 100 nucleotides.

Thermobifida fusca. In Thermobifida fusca, besides the dominant menaquinones, MK-10( $\left.\mathrm{H}_{6}\right)$ and MK$10\left(\mathrm{H}_{8}\right)$, substantial amounts of MK-11( $\left.\mathrm{H}_{6}\right)$ and MK11( $\left.\mathrm{H}_{8}\right)$ were recorded, whereas Thermobifida alba contained MK-10 $\left(\mathrm{H}_{10}\right)$ as the differentiating compound (Kroppenstedt \& Goodfellow, 1992). The peak area ratios of the dominant menaquinones showed no significant change when different incubation temperatures $\left(45\right.$ and $55^{\circ} \mathrm{C}$ ) were used, whereas the ratios of minor menaquinone components were influenced by temperature. All strains had PLII-type phospholipid composition according to Lechevalier et al. (1981): phosphatidylethanolamine, glycolipid and some unidentified phospholipids were identified. The diagnostic fatty acid pattern was similar in all strains. The amount of the $\mathrm{C}_{15}$-iso $+\mathrm{C}_{17}$-anteiso fraction was over $30 \%$, and the hydroxy and 10-methyl fractions were undetectable, indicating the presence of fatty acid pattern type $3 \mathrm{e}$, which is typical of actinomycetes belonging to the genus Thermobifida (Kroppenstedt \& Goodfellow, 1992). No mycolic acids were detected.

\section{Sequence comparison and phylogenetic analysis of 16S rRNA gene}

Strains studied in this work exhibited $99 \cdot 8-100 \%$ sequence similarity based on the analysis of the first $500 \mathrm{bp}$ of the $16 \mathrm{~S}$ rRNA gene, indicating a close interrelationship. A nearly complete sequence of the $16 \mathrm{~S}$ rRNA gene from strain $\mathrm{TB} 100^{\mathrm{T}}$ was determined. This sequence exhibited 97.4 and $97.8 \%$ similarity to the 16S rRNA gene of Thermobifida alba and Thermobifida fusca, respectively. The 16S rRNA sequences of Thermobifida alba and Thermobifida fusca share $97.5 \%$ similarity. These values support the separation of strain $\mathrm{TB} 100^{\mathrm{T}}$ from the two previously described
Thermobifida species. The topologies of the phylogenetic trees were very similar, and strain $\mathrm{TB} 100^{\mathrm{T}}$ clustered together with the genus Thermobifida with a bootstrap value of $87 \%$. The exact branching order of the two Thermobifida species and strain $\mathrm{TB} 100^{\mathrm{T}}$, however, was difficult to identify. In the tree prepared by maximum-parsimony analysis, Thermobifida alba was more closely related to strain $\mathrm{TB} 100^{\mathrm{T}}$ than to Thermobifida fusca, but, in the neighbour-joining and the De Soete tree, Thermobifida alba and Thermobifida fusca branched together and strain $\mathrm{TB} 100^{\mathrm{T}}$ formed a distinct cluster (Fig. 3). The bootstrap values of this branching point were similarly low when either the neighbour-joining or the maximum-parsimony treeing method was used.

\section{DNA base composition}

Thus far, data on the $\mathrm{G}+\mathrm{C}$ contents of the DNAs of any members of the genus Thermobifida have been lacking. In the present experiments, the $\mathrm{G}+\mathrm{C}$ contents of strains $\mathrm{K} 21, \mathrm{~TB} 100^{\mathrm{T}}$, $\mathrm{TB} 110$ and $\mathrm{TB} 108$ were determined as $70.6,70 \cdot 2,69.8$ and $70.3 \mathrm{~mol} \%$, respectively. The $\mathrm{G}+\mathrm{C}$ content of the reference strain, Thermobifida fusca ATCC $27730^{\mathrm{T}}$, was significantly lower, amounting to $66.5 \mathrm{~mol} \%$, a value comparable to the mean $\mathrm{G}+\mathrm{C}$ content of the genes that had until now been cloned and sequenced from Thermobifida fusca (Jung et al., 1993; Lao et al., 1991).

\section{DNA-DNA relatedness}

DNA-DNA reassociation studies were used to confirm the species status of the four new isolates in relation to the other two Thermobifida species described thus far. The results of DNA-DNA 
Table 3. Percentage DNA-DNA relatedness among the type strains of Thermobifida fusca ATCC $27730^{\top}$ and Thermobifida alba DSM $43795^{\top}$, as well as the newly described four strains of Thermobifida

Strains: $1, T$. fusca $\left(=\right.$ ATCC $\left.27730^{\mathrm{T}}\right) ; 2$, T. alba $(=\mathrm{DSM}$ $\left.43795^{\mathrm{T}}\right) ; 3$, TB110; 4, TB100 ${ }^{\mathrm{T}}\left(=\mathrm{DSM} 44535^{\mathrm{T}}\right) ; 5$, TB108; 6 , K21. Method used: thermal renaturation.

\begin{tabular}{|ccccccc|}
\hline Strain & $\mathbf{1}$ & $\mathbf{2}$ & $\mathbf{3}$ & $\mathbf{4}$ & $\mathbf{5}$ & $\mathbf{6}$ \\
\hline 1 & 100 & & & & & \\
2 & $33 \cdot 2$ & 100 & & & & \\
3 & $48 \cdot 4$ & $56 \cdot 8$ & 100 & & & \\
4 & $48 \cdot 1$ & 57 & $99 \cdot 1$ & 100 & & \\
5 & $49 \cdot 3$ & $57 \cdot 2$ & $98 \cdot 4$ & $98 \cdot 5$ & 100 & \\
6 & $46 \cdot 3$ & $53 \cdot 7$ & $94 \cdot 6$ & $95 \cdot 3$ & $96 \cdot 2$ & 100 \\
\hline
\end{tabular}

reassociation studies are presented in Table 3. These results confirmed the high degree of relatedness among the four new isolates found by $16 \mathrm{~S}$ rDNA sequence comparison. The DNA-DNA homology values were greater than $94.6 \%$, indicating that all four strains belong to a single species.

The new species status of these four isolates was further supported by the low reassociation values obtained in comparisons with Thermobifida fusca ATCC $27730^{\mathrm{T}}(46 \cdot 3-49 \cdot 3 \%)$ and Thermobifida alba DSM $43795^{\mathrm{T}}(53 \cdot 7-57 \cdot 2 \%)$. According to Wayne et al. (1987), two strains with less than $70 \%$ DNA homology belong to different species.

The morphological, physiological and chemotaxonomic properties, as well as the 16S rDNA sequence similarity, strongly support the affiliation of strains K21, TB100 ${ }^{\mathrm{T}}$, TB108 and TB110 to the genus Thermobifida (Zhang et al., 1998). We assign these four strains to a single species because of the high levels of similarity found in their $16 \mathrm{~S}$ rDNA sequences, menaquinone profiles and DNA G $+\mathrm{C}$ contents, as well as the strong relative homology observed among them in DNA-DNA hybridization experiments. Differences in colony morphology and physiological traits among the four strains remained within the boundaries of a species. On the other hand, these strains differ characteristically from Thermobifida fusca and Thermobifida alba in the above-mentioned traits. On the basis of these results, these four isolates were assigned to a new species named Thermobifida cellulolytica.

\section{Description of Thermobifida cellulolytica sp. nov.}

Thermobifida cellulolytica (cel.lu.lo.ly'ti.ca. N.L. n. cellulosum cellulose; Gr. adj. lyticus dissolving; N.L. fem. adj. cellulolytica cellulose-dissolving).

Aerobic, Gram-positive actinobacterium. Colonies on agar media bear abundant white aerial mycelium. Sporophores branch repeatedly to form dense spore clusters on aerial mycelium. The surfaces of the oval
$(1-1.3 \times 0.6 \mu \mathrm{m})$, heat-sensitive $\left(90{ }^{\circ} \mathrm{C}, 10 \mathrm{~min}\right)$ spores are scale-like. The growth temperature ranges of the thermotolerant and thermophilic strains are 28-45 and $40-65^{\circ} \mathrm{C}$, respectively. Crystalline cellulose, gelatin, starch, arbutin, elastin, xylan, Tween 20 and Tween 80 , but not chitin, are degraded. There is no acid production from glucose. D-Xylose, D-mannose, D-glucose, D-galactose, D-fructose, cellobiose, maltose, lactose, sucrose, trehalose and melezitose are used as sole carbon sources, but L-sorbose, glycerol, meso-inositol, dulcitol and D-sorbitol are not. Cultures grown on lignocellulose substrate produce endoglucanase, cellobiohydrolase, endoxylanase enzymes and are capable of solubilizing lignocarbohydrates. Growth is inhibited by novobiocin $\left(10 \mu \mathrm{g} \mathrm{ml}^{-1}\right)$, ampicillin $\left(10 \mu \mathrm{g} \mathrm{ml}^{-1}\right)$, chloramphenicol $\left(10 \mu \mathrm{g} \mathrm{ml}^{-1}\right)$, kanamycin $\left(2.5 \mu \mathrm{g} \mathrm{ml}^{-1}\right)$, streptomycin $\left(2.5 \mu \mathrm{g} \mathrm{ml}^{-1}\right)$, tetracycline hydrochloride $\left(5 \mu \mathrm{g} \mathrm{ml}^{-1}\right)$, apramycin $\left(2.5 \mu \mathrm{g} \mathrm{ml}^{-1}\right)$, thiostrepton $\left(1.25 \mu \mathrm{g} \mathrm{ml}^{-1}\right)$, penicillin $\left(10 \mu \mathrm{g} \mathrm{ml}^{-1}\right)$ and amoxycillin $\left(10 \mu \mathrm{g} \mathrm{ml}^{-1}\right)$. Resistant to erythromycin at $20 \mu \mathrm{g} \mathrm{ml}^{-1}$. The cell wall type is chemotype III, containing meso-diminopimelic acid without characteristic sugars. The menaquinone pattern is type $4 \mathrm{D}$; the dominant menaquinones are $\mathrm{MK}$ $10\left(\mathrm{H}_{8}\right)$ and MK-10 $\left(\mathrm{H}_{6}\right)$ with some uncommon menaquinones, including MK-11 $\left(\mathrm{H}_{6}\right)$, MK- $8\left(\mathrm{H}_{6}\right)$ and $\mathrm{MK}-$ $8\left(\mathrm{H}_{4}\right)$. The phospholipid pattern is type II (phosphatidylethanolamine, glycolipid) and the fatty acid pattern is type $3 \mathrm{e}$ (16:0 iso, 17:0 iso, 17:0 anteiso, 17:0 cyclo 9-10 type fatty acids are predominant). The $\mathrm{G}+\mathrm{C}$ content of the DNA is between 70 and $71 \mathrm{~mol} \%$. Isolated from overheated compost by J. Kukolya in 1997 at Gödöllö, Hungary. The type strain is strain TB100 ${ }^{\mathrm{T}}\left(=\mathrm{DSM} 44535^{\mathrm{T}}=\right.$ NCAIM B01997 $\left.{ }^{\mathrm{T}}\right)$.

\section{ACKNOWLEDGEMENTS}

We are deeply grateful to László Szabó for performing the scanning electron microscopy. This work was supported by grants from OTKA (T32407, A334, CO 021) and FKFP $(0315 / 99)$.

\section{REFERENCES}

Collins, M. D., Pirouz, T., Goodfellow, M. \& Minnikin, D. E. (1977). Distribution of menaquinones in actinomycetes and corynebacteria. $J$ Gen Microbiol 100, 221-230.

De Soete, G. (1983). A least squares algorithm for fitting additive trees to proximity data. Psychometrika 48, 621-626.

English, J. T., Láday, M., Bakonyi, J., Schoelz, J. E. \& Érsek, T. (1999). Phenotypic and molecular characterization of species hybrids derived from induced fusion of zoospores of Phytophtora capsici and Phytophtora nicotianae. Mycol Res 103, 1003-1008.

Fitch, W. M. (1971). Toward defining the course of evolution: minimum change for a specified tree topology. Syst Zool 20, 406-416.

Groth, I., Schumann, P., Weiss, N., Martin, K. \& Rainey, F. A. (1996). Agrococcus jenensis gen. nov., sp. nov., a new genus of actinomycetes with diaminobutyric acid in the cell wall. Int $J$ Syst Bacteriol 46, 234-239.

Groth, I., Schumann, P., Rainey, F. A., Martin, K., Schuetze, B. \& Augsten, K. (1997). Demetria terragena gen. nov., sp. nov., a new genus of actinomycetes isolated from compost soil. Int J Syst Bacteriol 47, 1129-1133. 
Hasegawa, T. \& Takizawa, M. (1983). A rapid analysis for chemical grouping of aerobic actinomycetes. J Gen Appl Microbiol 29, 319-322. Holt, J. G., Krieg, N. R., Sneath, P. H. A., Staley, J. T. \& Williams, S. T. (1994). Thermomonospora and related genera. In Bergey's Manual of Determinative Bacteriology, 9th edn, pp. 693-697. Edited by J. G. Holt. Baltimore: Williams \& Wilkins.

Hunter, I. S. (1985). Gene cloning in Streptomyces. In DNA Cloning. a Practical Approach, pp. 19-44. Edited by D. M. Glover. Oxford: IRL Press.

Jung, E. D., Lao, G., Irwin, D., Barr, B. K., Benjamin, A. \& Wilson, D. B. (1993). DNA sequences and expression in Streptomyces lividans of an exoglucanase gene and an endoglucanase gene from Thermomonospora fusca. Appl Environ Microbiol 59, 3032-3043.

Kroppenstedt, R. M. (1985). Fatty acid and menaquinone analysis of actinomycetes and related organisms. In Chemical Methods in Bacterial Systematics, pp. 173-199. Edited by M. Goodfellow \& D. E. Minnikin. London: Academic Press.

Kroppenstedt, R. M. \& Goodfellow, M. (1992). The family Thermomonosporaceae. In The Prokaryotes, pp. 1085-1110. Edited by A Balows, H. G. Trüper, M. Dworkin, W. Harder \& K. Schleifer. Berlin Springer.

Kukolya, J., Dobolyi, C. \& Hornok, L. (1997). Isolation and identification of thermophilic cellulolytic actinomycetes. Acta Phytopath Entomol Hung 32, 97-107.

Labeda, D. P. (1992). DNA-DNA hybridization in the systematics of Streptomyces. Gene 115, 249-253.

Lao, G., Ghangas, G. S., Jung, E. D. \& Wilson, D. B. (1991). DNA sequences of three $\beta$-1,4-endoglucanase genes from Thermomonospora fusca. J Bacteriol 173, 3397-3407.

Lechevalier, M. P., Stern, A. E. \& Lechevalier, H. A. (1981). Phospholipids in the taxonomy of actinomycetes. In Actinomycetes, pp. 393-405. Edited by K. P. Schaal \& G. Pulverer. Stuttgart: Gustav Fischer.

Maidak, B. L., Cole, J. R., Parker, C. T. \& 11 other authors (1999). A new version of the RDP (Ribosomal Database Project). Nucleic Acids Res 27, 171-173.
McCarthy, A. J. (1989). Thermomonospora and related genera. In Bergey's Manual of Systematic Bacteriology, vol. 4, pp. 2552-2572. Edited by S. T. Williams, M. E. Sharpe \& J. G. Holt. Baltimore: Williams \& Wilkins.

McCarthy, A. J. \& Cross, T. (1984). A taxonomic study of Thermomonospora and other monosporic actinomycetes. J Gen Microbiol 130, $5-25$.

Minnikin, D. E., Alshamaony, L. \& Goodfellow, M. (1975). Differentiation of Mycobacterium, Nocardia, and related taxa by thinlayer chromatographic analysis of whole-organism methanolysates. J Gen Microbiol 88, 200-204.

Minnikin, D. E., Collins, M. D. \& Goodfellow, M. (1979). Fatty acid and polar lipid composition in the classification of Cellulomonas, Oerskovia and related taxa. J Appl Bacteriol 47, 87-95.

Rainey, F. A., Ward-Rainey, N., Kroppenstedt, R. M. \& Stackebrandt, E. (1996). The genus Nocardiopsis represents a phylogenetically coherent taxon and a distinct actinomycete lineage: proposal of Nocardiopsaceae fam. nov. Int J Syst Bacteriol 46, 1088-1092.

Saitou, N. \& Nei, M. (1987). The neighbor-joining method: a new method for reconstructing phylogenetic trees. Mol Biol Evol 4, 406-425.

Sazci, A., Radford, A. \& Erenler, K. (1986). Detection of cellulolytic fungi by using Congo-red as an indicator: a comparative study with the dinitrosalicilic acid reagent method. J Appl Bacteriol 61, 559-562.

Stead, D. F., Sellwood, J. G., Wilson, J. \& Viney, I. (1992). Evaluation of commercial microbial identification system based on fatty acid profiles and rapid, accurate identification of plant pathogenic bacteria. J Appl Bacteriol 72, 315-321.

Trigo, C. \& Ball, A. S. (1994). Production of extracellular enzymes during the solubilization of straw by Thermomonospora fusca BD25. Appl Microbiol Biotechnol 41, 366-372.

Wayne, L. G., Brenner, D. J., Colwell, R. R. \& 9 other authors (1987). International Committee on Systematic Bacteriology. Report of the ad hoc committee on reconciliation of approaches to bacterial systematics. Int J Syst Bacteriol 37, 463-464.

Zhang, Z., Wang, Y. \& Ruan, J. (1998). Reclassification of Thermomonospora and Microtetraspora. Int J Syst Bacteriol 48, 411-422. 